The definitive, peer-reviewed and edited version of this article is published and can be cited as

Santos, G. and B. Shaffer (2004), 'Preliminary Results of the London Congestion Charging Scheme', Public Works, Management and Policy, Vol. 9, N², pp. 164-181. DOI: 10.1177/1087724X04268569

\title{
Preliminary Results of the London Congestion Charging Scheme
}

\section{Georgina Santos and Blake Shaffer}

\author{
Georgina Santos \\ Department of Applied Economics \\ University of Cambridge, UK \\ Georgina.Santos@econ.cam.ac.uk \\ Blake Shaffer \\ Faculty of Economics and Politics \\ University of Cambridge, UK \\ Blake.Shaffer@gmail.com
}




\begin{abstract}
On February $17^{\text {th }}, 2003$, the London Congestion Charging Scheme came into effect. Preliminary results show a significant response to the $£ 5$ (\$8) charge. Congestion over the first year decreased by 30 per cent, overall traffic levels within the charging zone fell by 16 per cent, speeds for car travel increased by over 20 per cent and bus travel became more reliable.

Elasticities of demand for trips by car with respect to generalized costs are estimated to be between -1.32 and -2.10 . The average marginal congestion cost within the central zone is estimated at $£ 1.65$ per veh-km (approximately $\$ 2.58$ per veh-km).

The net economic benefits of the Scheme for the first year were $£ 50$ million ( $\$ 78$ million) and the net revenues, $£ 68$ million (\$106 million). Net revenues are being mainly used to improve public transport.
\end{abstract}

\title{
KEY WORDS
}

Traffic congestion. London congestion charging. Demand elasticities. Congestion costs. Road pricing. 


\section{INTRODUCTION}

Garrett Hardin's Tragedy of the Commons (Hardin, 1968) depicts a classic example of the harmful effects of unabated negative externalities. In Hardin's story, the villagers of a small English town have equal and free access to a commons wherein they can place their animals. When making the decision to add a cow to the commons, a villager takes into account the animal's own ability to graze and roam, but not its effect on others. This is the classic description of the so-called free-rider problem commonly associated with public goods.

The modern version of Hardin's story could easily be depicted using drivers as, perhaps unflatteringly, the cows and roads in place of the commons. When a potential driver makes the decision to use private transport by comparing his marginal private costs and benefits he typically excludes from the analysis any external costs that his action of driving may impose upon others. Arthur Pigou, a Cambridge economist, first identified this problem of 'divergences between marginal social and private net products' in his book The Economics of Welfare (Pigou, 1920). To remedy this problem, Pigou proposed a tax or levy be imposed on drivers to ensure that their perceived private costs were consistent with the true social costs of driving.

More recently, the city of London has taken Pigou's idea from theory to practice. Since February $17^{\text {th }}, 2003$, motorists within the central London area are required to pay a $£ 5$ charge (approximately \$8) for the right to drive or park within the zone. The charge differs from a true Pigouvian tax in that it is not equal to the marginal congestion cost (MCC). A charge equal to the MCC would vary with time and location. Although technically the charge does differ temporally in that the license costs $£ 5$ between 7 am and $6.30 \mathrm{pm}$ from Monday to Friday, versus $£ 0$ at all other times, true marginal cost pricing (or Pigouvian taxation) would require more finely-tuned spatial and temporal differences. Nevertheless, the London Congestion Charging Scheme is a dramatic step towards internalizing the externalities associated with driving.

The aim of this paper is to analyze some of the preliminary effects, as recently published by Transport for London (TfL, 2003a, b, 2004). We briefly present the basic theory underlying optimal road pricing. We describe the London Scheme together with the preliminary results, which we then use to compute elasticities with respect to changes in generalized cost, as well as area marginal congestion costs. We then briefly touch on the costs and benefits of the Scheme, the use of revenues and the potential equity impacts. We conclude that the prevailing elasticities, as shown by motorists' response to the Scheme, are higher than it was expected, probably because of the public transport system in London, which provides and alternative to the car, and that the calculated area MCC suggests that the $£ 5$ charge is a reasonable approximate to marginal cost pricing.

\section{THE ECONOMICS OF CONGESTION CHARGING}

Sub-optimal levels of congestion are a result of drivers failing to take into account the effect that their vehicle will have on others. This 'neglected externality' means that drivers will often use private vehicles when the net marginal social benefit of doing so is actually negative. 
The optimal method of internalizing externalities is by marginal cost pricing, the basics of which were first proposed by Pigou (1920). The specific application of marginal cost pricing to a congested highway was more fully developed in a seminal paper by Walters (1961). Walters' model is based on engineering-related speed-flow relationships on links to derive the optimal congestion charge. The formal derivations are shown below, following Newbery (1990) and Nash (1997).

Assume a generalized travel cost per $\mathrm{km}$ function that consists of money costs (fuel, maintenance, etc) and time costs:

$$
g=m+\frac{b}{s(q)}
$$

where $g=$ generalized cost (pence per PCU-km)

$m=$ money cost (pence per PCU-km)

$b=$ value of time (pence per PCU-hour)

$s(q)=$ speed as a function of total flow (km per hour)

$q=$ flow (PCU per hour)

and PCU stands for passenger car unit, a measure of the relative disruption that different vehicle types impose on the network. A car for example, has a PCU rating of 1, whereas a light goods vehicles has a PCU rating of 1.5, etc. In the US passenger car equivalents (PCE) are used instead. The meaning however is the same.

Total costs (in pence per km-hour) are:

$$
C=g q=m q+\frac{b q}{s(q)}
$$

and marginal costs are:

$$
\frac{\partial C}{\partial q}=m+\frac{b}{s(q)}-\frac{b q}{[s(q)]^{2}} s^{\prime}(q)
$$

or more simply:

$$
\frac{\partial C}{\partial q}=g+\frac{b}{s(q)} e_{s q}
$$

where $e_{s q}$ is the elasticity of speed with respect to flow.

This last expression clearly identifies the marginal social costs as a function of marginal private costs, $g$, plus an external cost term, the congestion externality. By way of a Pigouvian tax, an individual's decision can be reconciled with the socially optimal choice. The tax in this case would be equal to $\frac{b}{s(q)} e_{s q}$ per PCU-km.

Although the above concept of first-best road pricing remains central to transport theory, its application to a congested urban design poses a few problems. To begin with, 
introducing marginal cost pricing in the transport sector does not guarantee an efficient outcome when there are externalities in other (related) sectors in the economy, which are not priced according to marginal cost. In addition to that, marginal cost pricing has proved difficult to implement in dense networks. In today's technologically advanced world the calculation of instant marginal cost pricing may not be very difficult to envisage. Its cost effectiveness however would be dubious and most importantly, the transparency of such a system would be at least arguable, as drivers would not know the congestion charge they would be required to pay before starting their journey. Marginal cost pricing would require highly differentiated pricing systems in time and space, which would be expensive to provide and confusing to users (Nash and Sansom, 2001).

Since marginal cost pricing is not very practical, transport economists have lately devoted their efforts to the study of second best alternatives (May et al, 2002; Verhoef, 2002; Shepherd and Sumalee, 2004; Zhang and Yang, 2004) and policy makers have opted for simpler, less expensive and more practical and transparent options such as cordon tolls and area licensing schemes. Such is the case of the original Singaporean scheme, the Norwegian toll rings and the new London area license scheme.

\section{THE LONDON CONGESTION CHARGING SCHEME}

The London Scheme can trace its origin back to the Smeed report (Ministry of Transport, 1964), which studied the technical feasibility of road pricing in the UK. Numerous studies have been produced since then, including the influential report by the TfL commissioned London Congestion Charging Research Programme (LCCRP) in 1995 (MVA Consultancy, 1995). The LCCRP Final Report suggests as its "medium" case a $£ 4$ electronic cordon toll (using Intra Vehicle Units) to enter a central London area, which is essentially identical to the ultimately chosen charging zone. The Road Charging Options for London (ROCOL) report published in 2000 followed the LCCRP. The ROCOL report (ROCOL Working Group, 2000) presents the technical details as well as predicted impacts of a variety of congestion reducing strategies including area licensing schemes and cordon tolls (central only and multi-zone; paper and electronic) as well as workplace parking levies.

The discussion became closer to reality in May 2000, when Ken Livingstone was elected Mayor of London based on a manifesto promising the introduction of congestion charging. The then-recently passed Greater London Authority (GLA) Act 1999 (Acts of Parliament, 1999) gave this new Mayor the power, for the first time, to impose congestion charges. ${ }^{1}$

The final decision, made by the Mayor, was to go with an area licensing scheme using a $£ 5$ charge applied to central London only. The method was chosen due to its relative ease of implementation as compared to full-scale road pricing. Automatic number plate recognition (ANPR) technology was selected as a "feasible intermediate" between

\footnotetext{
${ }^{1}$ The following year the Transport Act 2000 (Acts of Parliament, 2000) was passed, allowing for joint schemes, including ones involving London authorities, as long as the order has been submitted to and confirmed by the Greater London Authority. This power to make joint localLondon charging schemes does not limit any of the powers to introduce road user charging in Greater London given by the Greater London Authority Act 1999.
} 
an inexpensive but inefficient paper-based system and a sophisticated yet complex and expensive electronic road pricing scheme (ROCOL Working Group, 2000).

One of the key features of the run-up to the Scheme was the extensive consultation process, which took place over 18 months, and included meetings with key stakeholders, thousands of information leaflets on the proposed Scheme being distributed to all the 33 London boroughs and advertisements with details of the Scheme and how to participate in the consultation exercise being published in newspapers and broadcasted on radio stations. This consultation exercise increased the public acceptability of the Scheme.

\section{How the Scheme operates}

Figure 1 shows the limit of the area where the charges apply, the Inner Ring Road, which runs along Euston Road, Pentonville Road, City Road, Old Street, Commercial Street, Tower Bridge Road, New Kent Road, Kennington Lane, Vauxhall Bridge Road, Park Lane, Edgware Road and Marylebone Road. No charge is made for driving on the Inner Ring Road itself.

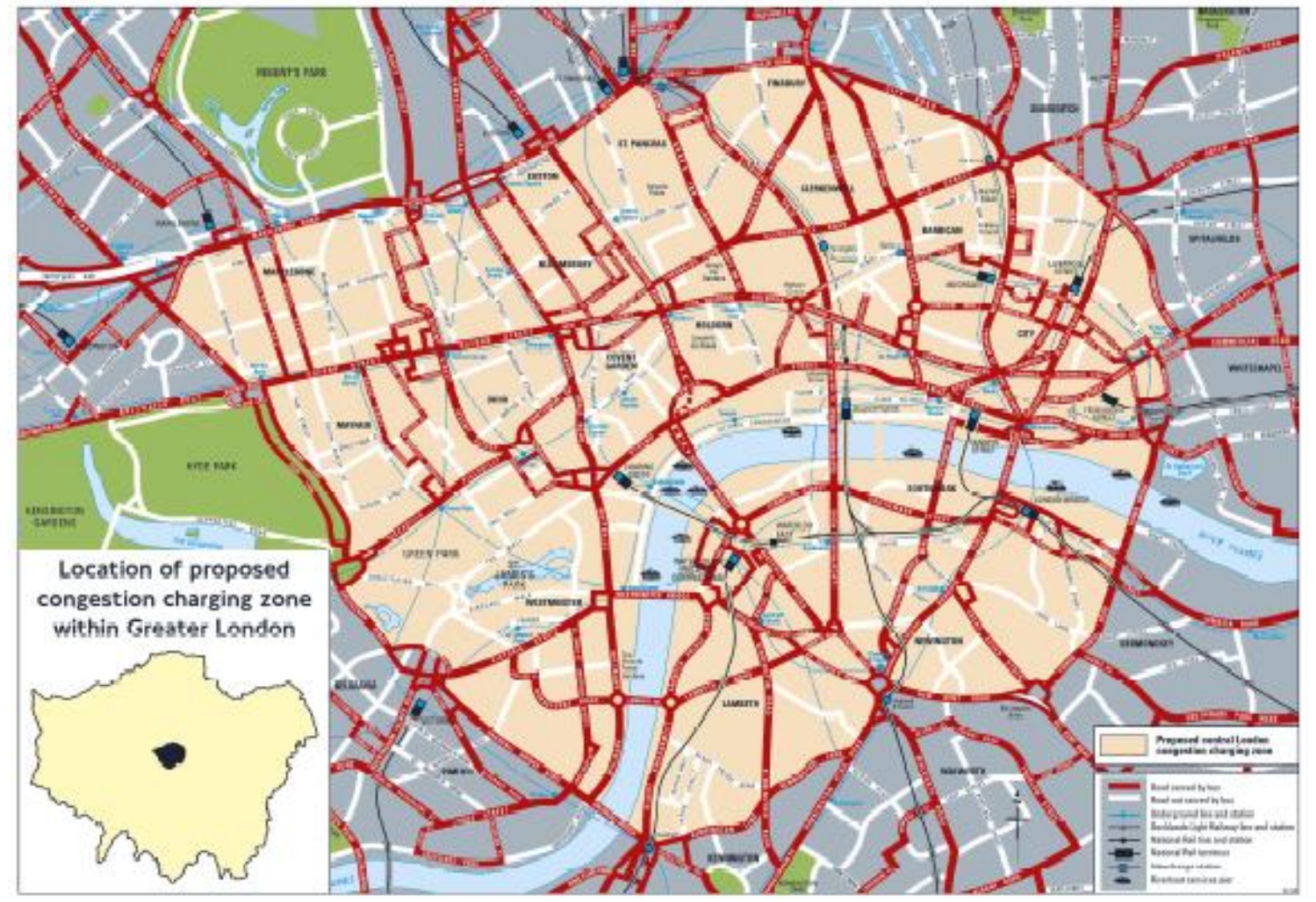

FIGURE 1 Map of the charging zone

Source: www.london.gov.uk/approot/mayor/congest/pdf/zone_map.pdf

Map reproduced with permission from Transport for London

We can see from the figure that the charging area is relatively small. It only covers $21 \mathrm{~km}^{2}\left(8 \mathrm{mi}^{2}\right)$, representing 1.3 per cent of the total $1,579 \mathrm{~km}^{2}\left(617 \mathrm{mi}^{2}\right)$ of Greater London. 
There are 174 entry and exit boundary points around the zone. Traffic signs make it clear where exactly the charging zone is. These are accompanied by a red symbol on each lane of traffic at the entry points to the charging zone. The Scheme charges all cars driving into or within the zone, as well as those parked in non-private spaces within the zone, regardless of movement. Essentially, one can consider the charge a 'daypass' for use of central London's roads. The ROCOL report (2000) used a further scenario encompassing all of 'inner London', as well as a differentiated-price scheme using both zones. Ultimately, it was thought that implementing the Scheme in the somewhat more manageable smaller size of central London would be more suitable as a first step, with the possibility of later expansion.

The applicable hours of the Scheme are 7 to 6.30pm, Monday to Friday, excluding bank and public holidays. This is a slight departure from the ROCOL recommendation of 7 am to $7 \mathrm{pm}$. The decision to change the evening end-time was primarily a result of lobbying by the entertainment community. It was argued that having the charge apply until 7pm would damage the West End as it would discourage theatre-goers from coming downtown.

The ROCOL consultants analyzed scenarios of $£ 2.50, £ 5$ and $£ 10$ charges using stated preference results from surveys as well as spatially-detailed representations of road traffic movements to estimate changes in travel conditions due to the introduction of area licensing. They predicted reductions in car trips and veh-km driven in Central London of 20-23 per cent (ROCOL Working Group, 2000, p.69-70). These predictions are not out of line with what has actually happened. TfL (2004) reports reductions in veh-km driven within the charging zone during charging hours of 15 per cent for vehicles with four or more wheels between 2002 and 2003. For potentially chargeable vehicles (cars, van and lorries) the reduction of veh-km driven has been 25 per cent. When only cars are considered, veh-km driven have been reduced by 34 per cent.

Due to the unsophisticated nature of an area licensing scheme, the system lacks the ability to adequately charge differentiated prices both temporally and spatially. Ultimately, the Mayor settled upon the $£ 5$ charge, deciding that it provided adequate incentive to achieve significant congestion reduction, but with less public backlash likely to be associated with a $£ 10$ charge. The heavy goods vehicle (HGV) charge, which was originally going to be $£ 15$ (three times the car charge), was reduced to be the same as that for cars.

The Scheme allows for a variety of 90-100 per cent discounts, as well as exemptions. A summary is shown in Table 1. 
TABLE 1 Exemptions and discounts

\begin{tabular}{|c|c|}
\hline Discount/Status & Category \\
\hline \multirow[t]{5}{*}{ Fully exempt } & Motorcycles, mopeds and bicycles \\
\hline & Emergency Vehicles \\
\hline & Public service vehicles with 9 or more seats licensed as buses \\
\hline & $\begin{array}{l}\text { Vehicles used by (and for) disabled persons that are exempt from } \\
\text { VED* }\end{array}$ \\
\hline & Licensed London taxis and mini-cabs \\
\hline \multirow{3}{*}{$\begin{array}{l}100 \% \text { discount with free } \\
\text { registration }\end{array}$} & Certain military vehicles \\
\hline & $\begin{array}{l}\text { Local government service vehicles (e.g. refuse trucks, street } \\
\text { maintenance) }\end{array}$ \\
\hline & $\begin{array}{l}\text { Vehicles with } 9 \text { or more seats not licensed as buses (e.g. community } \\
\text { minibuses) }\end{array}$ \\
\hline $\begin{array}{l}100 \% \text { discount with a } \\
\text { one-off } £ 10 \text { registration }\end{array}$ & $\begin{array}{l}\text { Vehicles driven by (or for) individuals or institutions that are Blue } \\
\text { Badge holders** }\end{array}$ \\
\hline \multirow[t]{2}{*}{$\begin{array}{l}100 \% \text { discount with } £ 10 \\
\text { registration }\end{array}$} & $\begin{array}{l}\text { Alternative fuel vehicles - requires emission savings } 40 \% \text { above Euro } \\
\text { IV standards }\end{array}$ \\
\hline & $\begin{array}{l}\text { Roadside assistance vehicles (e.g. motoring organizations such as the } \\
\text { Automobile Association) }\end{array}$ \\
\hline $\begin{array}{l}90 \% \text { discount with } £ 10 \\
\text { registration }\end{array}$ & Vehicles registered to residents of the central zone \\
\hline
\end{tabular}

Source: TfL, Congestion Charging Website

www.cclondon.com/exemptions.shtml

*VED: Vehicle excise duty

*** Blue Badges, which existed before the scheme was implemented, are special parking permits issued to disabled people to allow them to park near shops, stations, and other facilities. The badge belongs to the disabled person who qualifies for it (who may or may not be a car driver) and can be used in any vehicle they are traveling in.

Payments can be made by a variety of methods. These are shown in Table 2, along with their share of use during the first year. 
TABLE 2 Methods of payment

\begin{tabular}{||l|c||}
\hline \hline & $\begin{array}{c}\text { Percentage } \\
(\%)\end{array}$ \\
\hline Retail outlets & 36 \\
\hline Telephone & 19 \\
\hline Post & $<1$ \\
\hline Internet & 26 \\
\hline SMS text messaging & 19 \\
\hline
\end{tabular}

Source: Transport for London (2004, p.30)

Note: SMS: Short Message Service

The charge has to be paid in advance or on the day until 10pm with late payment available between 10pm and midnight but with the charge rising to $£ 10$ (\$16). The charge can be paid daily, weekly, monthly or yearly. It is at the drivers' initiative to pay the charge.

Enforcement is undertaken with video cameras. There is a network of 203 camera sites, with these located at every entrance and exit to the congestion charging zone as well as inside the charging zone. The cameras provide high-quality video signals to Automatic Number Plate Recognition (ANPR) software, which reads and records each number plate, with a 90 per cent accuracy rate. At midnight, images of all of the vehicles that have been in the congestion charging zone are checked against the vehicle registration numbers of vehicles which have paid their congestion charge for that day. The computer keeps the registration numbers of vehicles that should have paid but have not done so. A manual check of each recorded image is then made and a Penalty Charge Notice of $£ 80$ ( $\$ 126$ ) is then issued to the registered keeper of the vehicle. As with parking penalties, this amount is reduced to $£ 40$ (\$63) for prompt payment within 14 days. Failure to pay the penalty charge within 28 days results in the penalty being increased to $£ 120(\$ 190)$.

\section{PRELIMINARY RESULTS OF THE LONDON SCHEME}

In this section we summarize the traffic impacts of the Scheme over the first year.

\section{Effects on traffic}

According to TfL (2003a, b, 2004), the average travel speed in the charging zone in the first few months after the Scheme was implemented was $17 \mathrm{~km} / \mathrm{h}(10.6 \mathrm{mi} / \mathrm{h})$ and this continued over the first year. This number can be compared with the average speed precharging, which was $14 \mathrm{~km} / \mathrm{h}(8.7 \mathrm{mi} / \mathrm{h})$, as listed in the TfL First Annual Report (2003c, p.52). There has therefore been a 21 per cent increase in average travel speeds in the charging area. 
Congestion is defined by TfL as "the difference between the average network travel rate and the uncongested (free-flow) network travel rate in minutes per veh-km" (TfL, $2003 \mathrm{~b}, \mathrm{p} .46$ ). Using the uncongested network travel rate of $1.9 \mathrm{~min} / \mathrm{km}$ (approx. $32 \mathrm{~km} / \mathrm{h}$ ) from TfL (2003b, p.52), and pre- and post-charging average travel rates of 4.2 and 3.5 $\mathrm{min} / \mathrm{km}$ respectively, it can be seen that congestion has decreased from 2.3 to 1.6 $\mathrm{min} / \mathrm{km}$. Note that the optimal amount of congestion is not zero congestion. Zero congestion would suggest an under-use of road-space. On the other hand, TfL admits that there is an 'optimal' level of congestion, which is achieved at the 'optimal' level of traffic. However, it considers the optimal level of congestion difficult to define and that is the reason why it defines congestion using free-flow time as the base (TfL, 2003b). Bearing this caveat in mind, we can conclude that congestion has been reduced by 30.5 per cent. This calculated value is roughly equal to the listed value in the 'Update of Scheme Impacts and Operations' (TfL, 2004, point 1.8, p.4) of 30 per cent. Furthermore, it is in line, although at the upper end, with expectations of congestion reduction of between 20 and 30 per cent.

Traffic levels are a measure of the volume or number of vehicles entering or driving within central London. Compared to pre-charging conditions, the count of all cars entering the central zone has decreased by 31 per cent. However, the reduction in the number of cars has been partially offset by increases in incoming motorcycles (by 19 per cent), taxis (by 19 per cent) and buses (by 16 per cent). Traffic levels (all vehicles) inside the central zone have decreased by 15 per cent, again roughly in line (but at the upper end) with TfL's expectations of 10-15 per cent.

Finally, travel times have also showed significant improvements. Travel times to central London from outer London, inner London, and central London have all decreased. A basket of 5000 journeys from all areas of greater London showed a reduction in travel times of 13 per cent (TfL, 2003b, point 2.4, p.5).

A summary of the above results is shown in Table 3. 
TABLE 3 Preliminary effects on traffic

\begin{tabular}{|l|l|l|c||}
\hline & Pre-charging & Post-charging & $\begin{array}{c}\text { Change } \\
(\%)\end{array}$ \\
\hline \hline Average speed & $14 \mathrm{~km} / \mathrm{h}$ & $17 \mathrm{~km} / \mathrm{h}$ & +21 \\
\hline Congestion & $2.3 \mathrm{~min} / \mathrm{km}$ & $1.6 \mathrm{~min} / \mathrm{km}$ & -30.5 \\
\hline Traffic levels* & \multicolumn{3}{|l||}{} \\
\hline - incoming (cars only) & 193,912 & 133,016 & -31 \\
\hline - incoming (non-cars) & 178,149 & 193,485 & +9 \\
\hline - inside central zone & $\mathrm{n} / \mathrm{a}$ & $\mathrm{n} / \mathrm{a}$ & -16 \\
\hline Travel times to central zone & \multicolumn{3}{|l||}{} \\
\hline- from Outer London & $59 \mathrm{~min}$ & $52 \mathrm{~min}$ & -12 \\
\hline- from Inner London & $37 \mathrm{~min}$ & $33 \mathrm{~min}$ & -11 \\
\hline- from Central London & $38 \mathrm{~min}$ & $35 \mathrm{~min}$ & -8 \\
\hline- basket of 5000 journeys & $47 \mathrm{~min}$ & $41 \mathrm{~min}$ & -13 \\
\hline \hline
\end{tabular}

Source: Transport for London (2003a, b, Fig. 5, p.5)

*Data supplied by Transport for London on request Note: Pre-charging: spring 2002, Post-charging: spring 2003

Since traffic traveling on the Inner Ring Road does not pay the congestion charge, TfL expected that through traffic, with origin and destination outside the charging zone, would divert and use the Inner Ring Road instead. This indeed happened raising the total veh-km on the Inner Ring Road by 4 per cent when compared with 2002 (TfL, 2004). However, improved traffic management arrangements were put into place on the Inner Ring Road before the Scheme started and this prevented an increase in congestion. For example, between one and two seconds were taken off green light time on radial roads, which were anticipated would have less traffic, and added on to green light time on the Inner Ring Road. That made a sufficient difference to keep the Ring Road operating satisfactorily with marginally lower levels of congestion, when compared to pre-charging conditions.

Trafficmaster PLC, a private company that provides real-time traffic information on major routes, began a study on 17 February 2003 to assess the commuting impacts of the Scheme outside the zone. Although after six months of monitoring, average travel times recorded by Trafficmaster had increased on most routes, there were no constant patterns. Table 4 shows the average of travel times (in minutes) and travel time changes for the first seven months after the Scheme was introduced. We can see from the table that most routes had longer travel times. Table 5 gives some examples of how travel time on some routes increased and decreased in comparison to the same month the year before, and shows that there is no constant pattern of variation. 
TABLE 4 Average workday travel times into London (morning peak)

\begin{tabular}{|c|c|c|c|c|}
\hline Route & Orientation & $\begin{array}{c}\text { Feb-Sep } \\
2002 \\
(\min )\end{array}$ & $\begin{array}{c}\text { Feb-Sep } \\
2003 \\
(\mathrm{~min})\end{array}$ & $\begin{array}{c}\text { Change } \\
(\%)\end{array}$ \\
\hline A1 Mill Hill to Islington & N-NW & 46 & 49 & 7 \\
\hline A41 Mill Hill, Five Ways to Regent's Park & NW & 36 & 38 & 6 \\
\hline A40/M Denham to Marylebone & $\mathrm{W}$ & 62 & 61 & -3 \\
\hline A4 Langley, Slough to Talgarth Road & $\mathrm{W}$ & 57 & 57 & 1 \\
\hline A30 Stanwell to Osterley & W-SW & 15 & 16 & 6 \\
\hline A316 Sunbury Cross to Ravenscourt Park & W-SW & 40 & 41 & 2 \\
\hline A3 Cobham to Clapham & SW & 50 & 62 & 25 \\
\hline A23 Hooley to Brixton & $\mathrm{S}$ & 59 & 64 & 8 \\
\hline A20 Swanley to Eltham & SE & 20 & 23 & 14 \\
\hline A2/A102 Dartford to Blackwall Tunnel & E-SE & 39 & 44 & 14 \\
\hline A12 Harold Wood to Blackwall Tunnel & E-NE & 66 & 72 & 9 \\
\hline A10 Waltham Cross to Stoke Newington & $\mathrm{N}$ & 44 & 51 & 15 \\
\hline
\end{tabular}

Source: Trafficmaster PLC (data supplied on request)

TABLE 5 Examples of non-constant patterns in percentage changes in travel times

\begin{tabular}{|c|c|c|c|c|c|c|}
\hline Route & $\begin{array}{l}\text { April '02 } \\
\text { (min) }\end{array}$ & $\begin{array}{l}\text { April '03 } \\
\text { (min) }\end{array}$ & $\begin{array}{c}\text { Change } \\
(\%)\end{array}$ & $\begin{array}{c}\text { May '02 } \\
\text { (min) }\end{array}$ & $\begin{array}{c}\text { May '03 } \\
\text { (min) }\end{array}$ & $\begin{array}{c}\text { Change } \\
(\%)\end{array}$ \\
\hline $\begin{array}{l}\text { A1 Mill Hill to Islington } \\
\text { A41 Mill Hill, Five Ways to } \\
\text { Regent's Park } \\
\text { A40/M Denham to Marylebone } \\
\text { A4 Langley, Slough to Talgarth } \\
\text { Road } \\
\text { A30 Stanwell to Osterley } \\
\text { A316 Sunbury Cross to } \\
\text { Ravenscourt Park } \\
\text { A3 Cobham to Clapham } \\
\text { A23 Hooley to Brixton } \\
\text { A20 Swanley to Eltham } \\
\text { A2/A102 Dartford to Blackwall } \\
\text { Tunnel } \\
\text { A12 Harold Wood to Blackwall } \\
\text { Tunnel } \\
\text { A10 Waltham Cross to Stoke } \\
\text { Newington }\end{array}$ & $\begin{array}{c}50.1 \\
35.8 \\
65.4 \\
58.6 \\
16.5 \\
42.9 \\
58.4 \\
66 \\
23 \\
46.7 \\
72.5 \\
55.8\end{array}$ & $\begin{array}{l}51.7 \\
38.4 \\
68.9 \\
56.1 \\
17.5 \\
39.7 \\
59.3 \\
66.7 \\
23.2 \\
46.7 \\
70.7 \\
58.1\end{array}$ & $\begin{array}{c}3 \\
7 \\
5 \\
-4 \\
6 \\
-7 \\
2 \\
1 \\
1 \\
0 \\
-2 \\
4\end{array}$ & $\begin{array}{c}55.4 \\
42 \\
62.6 \\
64.4 \\
14.8 \\
44.3 \\
51.2 \\
64.8 \\
21.7 \\
40.7 \\
71.7 \\
53.4\end{array}$ & $\begin{array}{c}53.9 \\
46.4 \\
58.7 \\
59.7 \\
17.7 \\
48.4 \\
66 \\
71.6 \\
26 \\
45.8 \\
69.4 \\
57\end{array}$ & $\begin{array}{c}-3 \\
10 \\
-6 \\
-7 \\
20 \\
9 \\
29 \\
10 \\
20 \\
13 \\
-3 \\
7\end{array}$ \\
\hline
\end{tabular}

Source: Trafficmaster PLC (data supplied on request)

Note: Both months are within school term 
The apparent contradiction between Tables 3 and 4 can be explained by the fact that Table 4 measures travel times all the way up to and including the charging zone, where travel times have decreased and therefore push the average down. Table 4 on the other hand, does not include any road inside the charging zone.

\section{Effects on public transport}

TfL predicted that approximately 20,000 individuals would switch from car travel to public transport during the morning peak period as a result of the Scheme. Of this number, 5,000 were expected to use the Underground system, 14,000, the buses, with the remainder using rail system without transfers to bus or underground. It was also expected that the morning peak hour (8-9am) increase would be of an additional 7,000 bus users (TfL, 2002a).

Although bus ridership increased in line with expectations, Underground travel did not. Underground usage across London and specially in central London decreased. The reasons for the decrease in passenger levels on the London Underground are probably linked to the slowdown of the economy and the decrease in tourism in London, which in turn may be linked to the war in Iraq (TfL, 2003a). In addition to that, the Central Line was temporarily closed for almost three months following a derailment at Chancery Lane station in January.

Average bus speeds in the morning peak did not change too much and it is difficult to establish a pattern of variation. Whilst speeds on some route sections increased, speeds on others decreased (TfL, 2003a). On the other hand, additional time waited by passengers over and above the route schedule decreased by 25 per cent across Greater London and by over 33 per cent in the routes serving the Charging zone and the Inner Ring Road (TfL, 2003a, point 3.75). To accommodate the increase in bus ridership, TfL increased the number of buses in the central zone by 19 per cent over the year previous to the introduction of the Scheme. Further to this, there were also improvements such as the addition of new routes, switching 10 major routes from single-deck to double-deck buses, as well as adding 18-metre 'bendy' buses to heavily traveled routes.

The provision of good public transport is a key part of implementing a fair pricing scheme. If there are no, or inferior, public transport alternatives, then a road pricing scheme is just a regressive tax on the middle and poor classes. ${ }^{2}$ With good public transport, road pricing is to some degree a luxury tax - without it, it is just a regressive tax. TfL's increase in the bus service before and after the Scheme started is an example of changes that need to be a part of the process to promote fair social outcomes.

\section{Effects on other transport}

TfL (2003a, point 3.64) estimates that $15-25$ per cent of the reduction in car use per charging day is the result of car users switching to other modes of transport, such as car share, motorcycles, and bicycles, or by making adaptations such as altering travel plans to avoid the charging hours or charging zone, and walking. As can be seen from Table 6 the

\footnotetext{
${ }^{2} \mathrm{~A}$ brief discussion on the potential equity impacts of the Scheme is presented below.
} 
total count of bicycles and motorcycles going into the charging zone increased by 31 and 19 per cent respectively. Although both increases are higher than TfL's expectations (2003a, point 3.38), they are not surprising, giving the fact that neither of those vehicle categories pays the charge. Surprisingly enough, the number of powered 2 -wheelers (motorcycles and mopeds) and bicycles involved in accidents following the introduction of the Scheme fell by 15 per cent and 17 per cent respectively, when compared to the same period in 2002 (TfL, 2003a, point 3.97). These results probably reflect the longterm trend of declining accidents in London rather than any feature linked to the Scheme.

Incoming taxis also increased by 19 per cent, more than TfL expected (2003a, point 3.38). In addition, the count of working vehicles, such as Light Goods Vehicles and Heavy Goods Vehicles decreased.

Although when PCU ratings are taken into account the percentage changes change, the final results do not change too much, mainly as a consequence of traffic composition. Changes in vehicle counts and in PCU counts are all shown in Table 6. It can therefore be concluded that the increase in the use of buses, taxis, motorcycles and bicycles does not jeopardize the reduction in overall traffic, which has been larger than expected. There seem to be no grounds to extend the charge to include other vehicle categories, like it was done in Singapore. 
TABLE 6 Vehicle counts pre and post charging

\begin{tabular}{|c|c|c|c|c|c|c|c|c|c|c|c|}
\hline & $\begin{array}{l}\text { Pedal } \\
\text { Cycles }\end{array}$ & $\begin{array}{l}\text { Motor } \\
\text { Cycles }\end{array}$ & Cars & Taxis & $\begin{array}{l}\text { Bus \& } \\
\text { Coach }\end{array}$ & LGVs & $\begin{array}{c}\text { HGVs \& } \\
\text { Other }\end{array}$ & 4+ Wheels & Total & $\begin{array}{c}\text { Total non- } \\
\text { cars }\end{array}$ & $\begin{array}{l}\text { Pedal and } \\
\text { motorcycles }\end{array}$ \\
\hline Spring 2002 incoming & 13,836 & 25,840 & 193,912 & 55,971 & 13,393 & 53,780 & 15,329 & 332,386 & 372,062 & 178,149 & 39,676 \\
\hline Spring 2002 outgoing & 11,346 & 22,940 & 192,840 & 57,036 & 13,079 & 59,487 & 16,256 & 338,697 & 372,982 & 180,143 & 34,285 \\
\hline Spring 2002 total & 25,181 & 48,780 & 386,752 & 113,007 & 26,472 & 113,267 & 31,585 & 671,083 & 745,044 & 358,292 & 73,961 \\
\hline Spring 2003 incoming & 18,131 & 30,779 & 133,016 & 66,836 & 15,518 & 48,745 & 13,476 & 277,591 & 326,501 & 193,485 & 48,910 \\
\hline Spring 2003 outgoing & 12,535 & 25,426 & 125,151 & 64,917 & 15,735 & 50,660 & 14,402 & 270,865 & 308,826 & 183,675 & 37,961 \\
\hline Spring 2003 total & 30,666 & 56,205 & 258,168 & 131,753 & 31,253 & 99,405 & 27,878 & 548,456 & 635,328 & 377,160 & 86,871 \\
\hline Changes $(\%)$ & & & & & & & & & & & \\
\hline Incoming vehicles & 31 & 19 & -31 & 19 & 16 & -9 & -12 & -16 & -12 & 9 & 23 \\
\hline Outgoing vehicles & 10 & 11 & -35 & 14 & 20 & -15 & -11 & -20 & -17 & 2 & 11 \\
\hline Total vehicles & 22 & 15 & -33 & 17 & 18 & -12 & -12 & -18 & -15 & 5 & 17 \\
\hline PCU ratings & 0.2 & 0.5 & 1 & 1 & 2.5 & 1.5 & 2.5 & & & & \\
\hline Changes $(\%)$ & & & & & & & & & & & \\
\hline Incoming PCUs & & & & & & & & -14 & -13 & 3 & 21 \\
\hline Outgoing PCUs & & & & & & & & -17 & -16 & -1 & 11 \\
\hline Total PCUs & & & & & & & & -16 & -15 & 1 & 16 \\
\hline
\end{tabular}

Source: Transport for London, data provided on request

Note: PCU passenger car units, LGVs: Light Goods Vehicles, HGVs: Heavy Goods Vehicles 


\section{EMPIRICAL ANALYSIS}

This section includes a calculation of the elasticity of demand for car trips with respect to the generalized cost of travel, as well as a calculation of the marginal cost of congestion within the central London zone. The results are then compared with estimates from the literature.

\section{Price elasticity of demand}

An elasticity measures the percentage change in one variable with respect to a percentage change in another. In this context, we can use it to measure the responsiveness of demand for trips due to a change in travel costs. The generalized costs of travel include both money costs and time costs, as defined in Equation 1.

In order to proceed with the calculations, it is necessary to determine the average generalized cost of travel into central London. The UK Automobile Association provides detailed estimates of motoring costs (money costs) for cars, split out by fixed and variable costs (Automobile Association, 2003). The values depend on annual mileage (for fuel, maintenance, etc) and cost of vehicle (financing, insurance, depreciation).

We had to make several assumptions in selecting the appropriate measure of motoring costs. Firstly, we chose the Automobile Association's 'above-average' cost of car category to reflect the fact that the average Londoner has a higher income than the national average (National Statistics, 2003). The cost of a car affects the fixed costs of insurance and financing. To attain per $\mathrm{km}$ costs, we used the average annual distance driven by a Londoner of 8,800 km (5,466 mi) (TfL, 2001, p.2). The corresponding motoring costs for an average Londoner are thus roughly 47.5 pence $/ \mathrm{km}(\$ 1.2 / \mathrm{mi})$, of which 12.25 pence (20 cents) are variable costs. The motoring costs are presented in Table 7.

\section{TABLE 7 Motoring costs}

\begin{tabular}{||l|l|}
\hline \multicolumn{2}{|l|}{ Standing costs (£ annual) } \\
\hline Road tax & 160 \\
\hline Insurance & 448 \\
\hline Cost of capital & 412 \\
\hline Depreciation & 2080 \\
\hline \hline Standing costs total (pence per km) & 35.2 \\
\hline \hline Running costs (pence per $\mathrm{km}$ ) \\
\hline Fuel & 7.18 \\
\hline Service: tyres, parts and labor & 3.95 \\
\hline Parking & 1.13 \\
\hline \hline Running costs total (pence per km) & 12.25 \\
\hline \hline Total costs (pence per $\mathrm{km}$ ) & 47.48 \\
\hline \hline
\end{tabular}

Source: UK Automobile Association www.theaa.com/allaboutcars/advice/advice rcosts home.html 
To calculate time costs, it is necessary to determine a value of travel time savings (VTTS). The Transport Economics Note (Department of the Environment, Transport and the Regions, 2001) provides base figures and guidelines on how to estimate working and non-working VTTS. Another source for values of travel time savings in the UK is a report to the Department for Transport by Mackie et al (2003). This comprehensive report re-examines a substantial stated preference data set used in an earlier investigation commissioned by the same department in 1994. Additionally, the results are crossreferenced with those obtained from meta-analysis ${ }^{3}$. Table 8 details some of their recommended estimates.

TABLE 8 Estimates of the value of car travel time savings at end of 1997 values

\begin{tabular}{|l|c|c||}
\hline Income Band & Commuting $(\mathrm{p} / \mathrm{min})$ & Other $(\mathrm{p} / \mathrm{min})$ \\
\hline Below $£ 17,500$ & 3.6 & 4.6 \\
\hline$£ 17,500-£ 35,000$ & 5.9 & 5.9 \\
\hline Above $£ 35,000$ & 8.6 & 7.1 \\
\hline
\end{tabular}

Source: Mackie et al (2003)

Note: $\mathrm{p} / \mathrm{min}$ : pence per minute

Although we computed the elasticity of demand following the Transport Economics Note (Department of the Environment, Transport and the Regions, 2001) in the first instance, we also used another set of values following the recommendations in Mackie et al (2003). The main difference between the two documents is that Mackie et al (2003) recognizes that although commuting trips are non-working they tend to have a slightly higher VTTS than shopping or leisure trips. ${ }^{4}$

In order to produce working and non-working VTTS following the Transport Economics Note (Department of the Environment, Transport and the Regions, 2001), we updated the values given there to 2003 prices. We also increased the working value of time by 34 per cent, to reflect the difference in the average earnings in London, as indicated in the New Earnings Survey 2003 (National Statistics, 2003). We considered two categories of trips: working, as trips made in the course of work, excluding commuting, and non-working. We estimated the working VTTS at 42.2 pence/min and the non-working VTTS at 4.9 pence/min. TfL provided us with provisional data indicating that 10 per cent of car trips in London are business trips. The weighted VTTS we used was therefore 8.6 pence/min. Using the average car occupancy rate of 1.35 (TfL, 2002 b, p.19), this amounts to 11.7 pence/PCU-min. Other numbers needed to calculate the elasticities are shown in Table 9.

\footnotetext{
${ }^{3}$ Statistical analysis that involves integrating results of many independent studies on the same issue.

${ }^{4}$ This is probably because of the potential penalty for arriving late.
} 
TABLE 9 Details of an average trip by car in London

\begin{tabular}{||l|l|}
\hline Distance traveled per day* & $23.4 \mathrm{~km}$ \\
\hline Time traveled per day (pre-charging)** & $94 \mathrm{~min}$ \\
\hline Time savings per day (post-charging) & $12 \mathrm{~min}$ \\
\hline Vehicle costs & $47.5 \mathrm{pence} / \mathrm{km}$ \\
\hline Running costs & $12.3 \mathrm{pence} / \mathrm{km}$ \\
\hline Value of time per car & $11.7 \mathrm{pence} / \mathrm{min}$ \\
\hline Average occupancy & 1.35 \\
\hline
\end{tabular}

Source: see text

*TfL concludes that the average car trip in London is $11.7 \mathrm{~km}$ (TfL, 2002, Table 7.1, p.25) and two trips per day are assumed in this study **For travel times, see Table 3

Using all this information, we computed the percentage change in generalized costs. We estimated elasticities of demand for trips by car with respect to changes in generalized costs including all vehicle costs, as well as generalized costs including time costs and car running costs but excluding fixed costs. For a change in travel demand, the appropriate statistic is the 31 per cent reduction in car travel entering the central zone. This statistic best represents the demand response of those who are not exempt from the charge, such as residents. Unfortunately it is not possible to determine whether the reduction in demand for car trips is entirely the result of the charge or the result of a combination of factors in addition to the charge, such as for example, the economic slowdown.

Table 10 presents the results. The most relevant value in the short run is -1.32 , as that excludes fixed costs from the calculations. 
TABLE 10 Elasticities of demand for car trips with respect to costs

\begin{tabular}{|c|c|c|}
\hline & All GC & $\begin{array}{l}\text { GC exc. } \\
\text { fixed } \\
\text { costs }\end{array}$ \\
\hline Occupancy rate & 1.35 & 1.35 \\
\hline Average car trip $(\mathrm{km})$ & 11.7 & 11.7 \\
\hline Number of trips per day & 2 & 2 \\
\hline VTTS per person (pence/min) & 8.6 & 8.6 \\
\hline Time per trip (min) & 47 & 47 \\
\hline Time savings per trip (min) & 6 & 6 \\
\hline Vehicle operating costs (pence/km) & 47.5 & 12.3 \\
\hline GC per day $(\mathfrak{E})$ & 22.07 & 13.82 \\
\hline Toll $(\mathfrak{£})$ & 5.00 & 5.00 \\
\hline Time Benefits $(£)$ & 1.40 & 1.40 \\
\hline Reliability Benefits* $(\mathfrak{f})$ & 0.35 & 0.35 \\
\hline Change in GC (£) & -3.25 & -3.25 \\
\hline Change in GC (\%) & -14.7 & -23.5 \\
\hline Change in Demand (\%) & 31 & 31 \\
\hline Elasticity & -2.1 & -1.3 \\
\hline
\end{tabular}

Source: own calculations with numbers from Tables 7 and 9

*Dodgson et al (2002) argue that reliability benefits are worth approximately $25 \%$ of time benefits.

For the calculations following Mackie et al (2003) we considered three categories of trips: working, commuting, and other. 10 per cent of all trips made by car in London are for business purposes, 26 per cent for commuting, and 64 per cent for other purposes such as leisure, shopping, etc. ${ }^{5}$ We derived the value of working time from the gross weekly earning in London indicated in the New Earnings Survey 2003 (National Statistics, 2003). We took the VTTS for commuting and other purposes for different income levels from Mackie et al (2003), updated them to 2003 values, and calibrated them to the average salary in London. In this way, we estimated the average VTTS at 32.9 pence/min, 7.7 pence/min, and 6.4 pence/min for working, commuting, and other purpose car trips. The weighted VTTS we used was therefore 9.4 pence/min, equivalent to $12.7 \mathrm{pence} / \mathrm{min}$, assuming a car occupancy rate of 1.35 . Thus, we obtained elasticities of -2.5 and -1.6 , very similar to -2.1 and -1.3 of Table 10 .

Literature regarding elasticities of demand with respect to congestion charges is relatively rare. In Singapore, however, where charges are revised regularly, there has been considerable scope for evaluating effects of price changes. Dodgson et al (2002) summarize various studies for Singapore suggesting point elasticities in the order of -0.12 to -0.35 with respect to congestion charges.

\footnotetext{
${ }^{5}$ These figures were provided by TfL on request and are part of the London Area Transport Survey 2001, Household Survey, Interim weighted data. They will be included in the London Travel Report 2003 when it is published.
} 
More commonly calculated are elasticities of demand with respect to fuel prices. Goodwin (1992) calculated short-run and long-run elasticities of -0.16 and -0.32 respectively. These numbers are still considered standard values for the responsiveness of car travel demand with respect to changes in fuel prices (Graham and Glaister, 2002).

As a general rule, the sensitivity of demand to generalized cost changes will broadly be equal to the fuel price elasticity divided by the fuel share of generalized cost (Dodgson et al, 2002, p.28). For example, if fuel costs change by 10 per cent, but the share of fuel costs in terms of total costs is only one quarter, then generalized costs have changed by only 2.5 per cent. In heavily congested London, where time costs have a much larger share of total costs, the share of fuel costs can be estimated at roughly 8-16 per cent, with the higher range going to the 'running costs only' scenarios. Therefore, Goodwin's value of -0.16 for short-run fuel price elasticity corresponds to a generalized cost elasticity of between -1.3 and -2.1 , which are exactly the values computed in Table 10 .

These high elasticities in London are probably linked to the wide availability of public transport. In a region with poor public transport alternatives we would expect to observe a lower elasticity of demand for travel by car.

\section{Marginal congestion cost}

As explained earlier, the MCC is equal to the value of time divided by speed, then multiplied by the elasticity of speed with respect to flow.

$$
M C C=\frac{b}{s(q)} e_{s q}
$$

This expression has typically been used to compute the MCC of vehicles on a given link. Here the same expression is used to compute an 'area MCC', where traffic is assumed to be homogeneous within the small, congested central zone with disregard for link versus intersection differences.

The calculations within the central zone can thus be carried out assuming that speed within the zone has risen from $14 \mathrm{~km} / \mathrm{h}$ to $17 \mathrm{~km} / \mathrm{h}$ ( 21 per cent increase) and total traffic levels, measured in PCUs and including all vehicle types, have decreased by 15 per cent, as indicated in Table 6.

The average VTTS within the central zone was estimated at 29.6 pence per PCU-min at 2003 prices. This value was computed using the pre-charging shares of traffic as implied by Table 6, their associated PCU values and occupancy rates, and trip purposes as provided by TfL on request. Following the practice set for the London Congestion Charging Research Programme (MVA Consultancy, 1995) and for the ROCOL study (ROCOL Working Group, 2000) a single value of time was used for all modes in the case of working time, and a single value of time was used for all person types in the case of non-working time.

Ordinarily, flow is measured in terms of vehicles per hour on a link, however, in the context of an urban setting, this link-based measurement is less applicable. Therefore, the use of traffic volumes serves as a better proxy for flow in urban areas. Using this data, the implied area marginal cost of congestion is: 


$$
M C C=\frac{29.6 \times 60}{14} \times \frac{0.21}{0.15}=186.5 \text { pence } / \mathrm{PCU}-\mathrm{km} .
$$

When converted to veh-km from PCU-km using an average PCU/veh rate of 1.13, the calculated MCC is 165 pence/veh-km at 2003 prices. This calculated MCC value is higher than the value computed by Sansom et al (2001), who by estimating speed-flow relationships for a variety of road settings, calculated a MCC of 86 pence/veh-km updated to 2003 prices in a major urban center such as London. The values we estimated here however rest on the latest data and empirical evidence and are therefore more reliable.

The estimated area MCC of $£ 1.65$ illustrates that in order for the $£ 5$ congestion charge to reflect on average the congestion externality, an average vehicle would need to travel a distance of about $3 \mathrm{~km}$ per day inside the charging zone, which is a reasonable expectation given that the zone has a diameter of roughly $5 \mathrm{~km}$.

\section{COSTS AND BENEFITS}

The capital costs of the Scheme were approximately $£ 200$ million at 2003 prices, most of which were provided by the central government ${ }^{6}$. The annual operational costs and benefits are presented in Table 11, as detailed in the Six Months On report (TfL, 2003a). The table suggests a net benefit of around $£ 50$ million for the first year of operation.

\section{TABLE 11 Preliminary estimates of the annual costs and benefits of the London} Scheme (£ million at 2003 prices)

\begin{tabular}{||l|c||}
\hline Annual Costs & \\
\hline TfL administrative and other costs & 5 \\
\hline Scheme operation & 90 \\
\hline Additional bus costs & 20 \\
\hline Chargepayer compliance costs & 15 \\
\hline Total & $\mathbf{1 3 0}$ \\
\hline Annual Benefits & \\
\hline Time savings to car and taxi occupants, business use & 75 \\
\hline Time savings to car and taxi occupants, private use & 40 \\
\hline Time savings to commercial vehicle occupants & 20 \\
\hline Times savings to bus passengers & 20 \\
\hline Reliability benefits to car, taxi and commercial vehicle occupants & 10 \\
\hline Reliability benefits to bus passengers & 10 \\
\hline Vehicle fuel and operating savings & 10 \\
\hline Accident savings & 15 \\
\hline Disbenefit to car occupants transferring to public transport, etc & -20 \\
\hline Total & $\mathbf{1 8 0}$ \\
\hline
\end{tabular}

Source: TfL (2003a, Table 3)

\footnotetext{
${ }^{6}$ Information provided by TfL.
} 
A five-year monitoring programme has been set up, one year before the start of charging and four years after. It consists of over 100 surveys and studies, designed to measure and understand the impacts of the Scheme. Although one year into the Scheme may still be early to draw any conclusions, it is clear that the Scheme will have economic, social and environmental impacts. The monitoring programme is already assessing all these different aspects and Transport for London will produce annual reports describing and explaining them.

Westminster City Council conducted a survey to find out how businesses felt about the congestion charge. From all the respondents, 68 per cent have their businesses inside the charging zone, 44 per cent are retailers and 27 per cent are bars and/or restaurants (Westminster City Council, 2003). Almost 69 per cent of the respondents feel the Scheme has had a negative impact on their business, 8 per cent feel it has had a positive impact, and 23 per cent feel it has had no impact. Almost 28 per cent of the respondents are considering relocating outside of the zone as a result of the charge.

During October and November 2003 TfL carried out interview surveys of over 700 businesses in and around the charging zone. Concerns about the negative impact of the Scheme have mainly come from the retail and leisure sectors, which reported a 2 per cent reduction in sales for the first half of 2003 (TfL, 2004). According to these sectors, the reasons for the decline in sales were economic and tourism factors, though congestion charging constituted about a fifth of the reported causes (TfL, 2004).

TfL (2004) presents some preliminary evidence of the relationship between the reduction in sales, tourism and Underground patronage. The main conclusion is that retail sales and tourism numbers are strongly correlated and show a negative trend during the first months of 2003. Underground patronage during 2003 was 7-10 per cent lower in the charging zone and 4-7 per cent lower across the entire network, when compared with 2002. When Underground travel is added on to the analysis, the significant reductions in Underground travel during Spring 2003 (reflecting not only lower tourism levels but also the Central line closure) coincide with the period of negative retail growth (TfL, 2004, p.25). Although the exact impact cannot be quantified there is clearly a link between the decline in Underground travel and in sales in the charging zone. If anything the Scheme encouraged the switch from the car to the Underground, so a reduction in Underground travel cannot be linked to the Scheme in any way.

There are positive externalities from having a central area where the centers of government, law, business, finance, retail activity and entertainment are concentrated. With businesses considering relocation in the long run the benefits of the Scheme would be affected by losses in social welfare, mainly result of the loss of these positive externalities. It is early to determine what the trend will be and some more monitoring is needed before any conclusions can be drawn.

\section{USE OF REVENUES}

The Mayor's Transport Strategy (GLA, 2001), as well as congestion reduction, also includes objectives such as investing in the Underground, improving bus services and integrating National Rail with other transport systems. The GLA Act 1999 (Acts of Parliament, 1999) ensures that revenues from charging schemes will be earmarked for the Mayor's Transport Strategy projects for at least ten years from their implementation date. 
Transport investment in London has been inadequate since the mid 1980s, and therefore unable to accommodate economic and demographic growth, resulting in high levels of congestion together with overcrowded and unreliable public transport (GLA, 2001, p.23). The plan is to revert the situation by delivering the necessary additional public transport capacity and reliability in conjunction with demand management policies, such as congestion charging.

The Scheme raised $£ 68$ million in $2003 / 04$ and it is expected to raise $£ 80$ to $£ 100$ million in future years for investment in transport. ${ }^{7}$ Transport improvements in London in 2003/04 totaled $£ 82.8$ million at 2003 prices. The difference was covered with resources that become available from other sources such as increased revenues from public transport. ${ }^{8}$ TfL constantly monitors changes in revenues from the Scheme, other incomes and expenditure, and constantly adjusts the budget appropriately and makes reallocations where necessary.

The Mayor's Annual Report (GLA, 2004, p.51) gives details of the transport improvements carried out in the period 2003/04. Of the $£ 82.8$ million, $£ 62.8$ million were allocated to bus network improvements (higher frequencies, additional routes, enhanced route supervision and conversion to higher capacity routes); $£ 10.5$ million were allocated to road safety (research, engineering works, and education campaigns); $£ 2$ million were allocated to safer routes to schools, $£ 6$ million to walking and cycling (strategic and local engineering schemes on all London's roads as well as information campaigns); and $£ 1.5$ million to freight (measures to make the distribution of goods more sustainable).

The fact that revenues are being returned to the transport sector is a very important factor in the success of the Scheme. Londoners can see where the money is going. The integrated nature of TfL seems to be a good example of the kind of coordination that may produce good social outcomes from a pricing scheme.

\section{EQUITY IMPACTS}

A regressive tax is a tax that takes a larger percentage of the income of low income people than of high income people. Strictly speaking, a congestion charge would not be a tax but it would be perceived as a tax by the motoring public. According to the System of National Accounts 1993 (Commission of the European Communities et al, 1993) taxes are 'compulsory, unrequited payments' for which 'the government provides nothing in return to the individual unit making the payment, although governments may use the funds raised in taxes to provide goods or services to other units'.

Whilst congestion charges are not taxes, they are still regressive in the sense that they do not vary with income (i.e. the charge paid by drivers is the same regardless of their income). A daily toll of $£ 5$ to drive into central London, for example, represents a larger percentage of the income of low income people than of the income of high income people.

In that sense the Scheme may be having perverse impacts on lower income groups. Although the answer to this problem would be a switch to public transport, the necessary conditions of reliability, safety and frequency may have been met during the times of

\footnotetext{
${ }^{7}$ Even though net revenues were $£ 69$ million (\$108 million), net economic benefits were $£ 50$ million (\$78 million).

${ }^{8}$ Information provided by GLA on request.
} 
operation of the Scheme but not during other times and this may pose a problem. For example, when low income workers drive into the charging area at early hours in the morning ( 2 am for some butchers) the charge does not apply, yet they have to pay the charge when they finish work later in the morning and want to leave the zone to drive home. Public transport during the night is perceived as not frequent, safe or reliable and these low income workers have to choose between the inconvenience of traveling by bus or paying the charge when they finish work. Having said all this, the five year monitoring program will assess any impacts on equity when more evidence becomes available.

With the data on traffic counts presented in Table 6 and the occupancy rates given in the London Travel Report 2002 (TfL, 2002b, Table 5.1, p.19) and in the Transport Economics Note (Department of the Environment, Transport and the Regions, 2001, Table 2/3), we can conclude that 52 per cent of all people traveling to or from the charging zone used buses before the Scheme was introduced. If taxi and pedal and motorcycle users are added as well, the total share of people that did not use a chargeable mode of transport before the Scheme raises to 63.9 per cent. These are winners, in the sense that they are enjoying lower congestion without paying a penny, and they do not have any disutility from changing mode because they did not change mode. From a very conservative point of view the remaining 36.1 per cent would be losers. However, those with very high values of time also have a net benefit after paying the congestion charge. In addition to that, there are a number of exemptions and discounts, as given in Table 1. The share of people traveling by car was reduced from 27 per cent to 18 per cent, which means that 9 per cent of the original car users have transferred to some other mode or made alternative arrangements. This is the group listed in the second part of Table 11 as having a disbenefit of $£ 20$ million.

\section{CONCLUSIONS}

The preliminary results suggest that the London Scheme has so far been successful in achieving the stated congestion reduction targets. Traffic reduction has been higher than expected, which means that elasticities might have been underestimated prior to the implementation of the Scheme. Goodwin (2003) suggests that elasticities were revised down by a sort of 'ratchet' effect from one study to the next, probably because their authors wanted to be conservative, and would always choose the lowest estimate. The fact that public transport in London was substantially improved before the Scheme started, thus providing an alternative to the private car, may be the reason for these high elasticities of demand.

The calculated area MCC suggests that the $£ 5$ charge is a reasonable approximate to marginal cost pricing.

The largest potential hurdle, the political one, is perhaps where the largest success has been made. While economists have suggested for over 80 years now that drivers should face the true social cost of their actions, it is inevitably a politically unpopular decision to implement any form of charge on the act of driving. However, despite this, there has been surprisingly little public backlash. One of the reasons for this success is that the system is simple, feasible and transparent. Furthermore, the hypothecation of revenues, guaranteed by the Greater London Authority Act 1999 (Acts of Parliament, 1999), and a lengthy consultation process that preceded the introduction of the Scheme provided a feeling of trust to the public in knowing where their money would be spent. Surveys carried out by 
Market \& Opinion Research International, an independently-owned market research company in the UK, show that although only 50 per cent of London residents support the Scheme, 73 per cent think it has been effective at reducing congestion (Market \& Opinion Research International, 2003).

Public consultation on a revision to the Mayor's Transport Strategy began on 16 February 2004 for ten weeks. The revision would allow an extension of the charging zone to include parts of the City of Westminster and the Royal Borough of Kensington and Chelsea (GLA, 2004, p.52). This reform, which would double the size of the charging area, would imply higher revenues, which would allow higher investment in public transport.

In London, where traffic had returned to speeds of 100 years ago (TfL, 2002c) the costs of congestion were recognized as being too high and the public acknowledged that supply-side measures do not work in themselves. The introduction of congestion charging to one of the major cities of the world is perhaps a sign that the world is ready to shift road pricing from its theoretical hideaway to a practical center-stage.

\section{ACKNOWLEDGEMENTS}

We are grateful to Jeremy Evans, Simon Burton, Charles Buckingham, Sharon Cartwright, Ruth Excell and Karen Grayson, from Transport for London, to Kevin Austin and Richard Tribe from the Greater London Authority, and to Georgina Osbourn, from Trafficmaster PLC, for provision of data. We are also indebted to David Reams, Ken Small and three anonymous referees for comments on an earlier draft. Any remaining errors are the authors' sole responsibility. Support from the British Academy for Georgina Santos is gratefully acknowledged. 


\section{REFERENCES}

Acts of Parliament (1999). Greater London Authority Act 1999 c. 29, London: HMSO, November. www.hmso.gov.uk/acts/acts1999/19990029.htm. Accessed on March 24, 2003.

Acts of Parliament (2000). Transport Act 2000 c. 38, London: HMSO, December.

Automobile Association (2003). Your Guide to Motoring Costs. Automobile Association. www.theaa.com/allaboutcars/advice/advice_rcosts_home.html. Accessed on July 2, 2003.

Commission of the European Communities, International Monetary Fund, Organisation for Economic Co-operation and Development, United Nations, and World Bank (1993). System of National Accounts 1993. Brussels, Luxembourg, New York, Paris, Washington D.C.

Department of the Environment, Transport and the Regions (2001). Transport Economics Note. March.

www.dft.gov.uk/stellent/groups/dft transstrat/documents/page/dft transstrat 504865. hcsp. Accessed October 27, 2003.

Dodgson, J., Young, J. and van der Veer, J. (2002). Paying for Road Use, Technical Report, A report to the Commission for Integrated Transport, National Economic Research Associates (NERA), London, February 2002. www.cfit.gov.uk/research/pfru/pdf/pfru-tech.pdf. Accessed on March 1, 2003.

Goodwin, P. B. (1992). A Review of New Demand Elasticities with Reference to Short and Long Run Effects to Price Changes. Journal of Transport Economics and Policy, 26(2), 155-169.

Goodwin, P. (2003). The Economic Cost of Congestion when Road Capacity is Constrained: Lessons from Congestion Charging in London. CD-ROM $16^{\text {th }}$ International Symposium on Theory and Practice in Transport Economics of the European Conference of Ministers of Transport, Budapest, October 29-31.

Graham, D. and Glaister, S. (2002). The Demand for Automobile Fuel: A Survey of Elasticities, Journal of Transport Economics and Policy, 36(1), 1-25.

Greater London Authority (2001) The Mayor's Transport Strategy. London: Greater London Authority. www.london.gov.uk/mayor/strategies/transport/trans strat.jsp

Greater London Authority (2004). The Mayor's Annual Report 2004. London: Greater London Authority. www.london.gov.uk/mayor/annual_report/docs/ann_rpt_2004.pdf

Hardin, G. (1968). The Tragedy of the Commons. Science, 162(3859), Dec. 13, 12431248.

Mackie, P., Wardman, M., Fowkes, A., Whelan, G., Nellthorp, J. and Bates, J. (2003). Values of Travel Time Savings in the UK-Summary Report, Report to the Department of Transport. Institute for Transport Studies, University of Leeds. www.its.leeds.ac.uk/working/downloads/VOTSummary.pdf

Market \& Opinion Research International (2003). Poll \& Surveys Archive: London Mayor Ratings. July 9. www.mori.com/polls/2003/gla-june.shtml. Accessed on November 4, 2003.

May, A. D., Liu, R., Shepherd, S. P. and Sumalee, A. (2002). The Impact of Cordon Design on the Performance of Road Pricing Schemes. Transport Policy, 9(3), 209220. 
Ministry of Transport (1964). Road Pricing: The Economic and Technical Possibilities. London: HMSO.

MVA Consultancy (1995). The London Congestion Charging Research Programme: Final Report. London: HMSO.

Nash, C. (1997). Transport Externalities: Does Monetary Valuation Make Sense? In de Rus, G. and C. Nash (Eds.). Recent Developments in Transport Economic. Aldershot: Ashgate, 232-254.

Nash, C. and Sansom, T. (2001). Pricing European Transport Systems. Journal of Transport Economics and Policy, 35(3) 2001, 363-380.

National Statistics (2003). New Earnings Survey 2003. October. www.statistics.gov.uk/pdfdir/nes1003.pdf. Accessed October 28, 2003.

Newbery, D. M. (1990). Pricing and Congestion: Economic Principles Relevant to Pricing Roads. Oxford Review of Economic Policy, 6(2), 22-38.

Pigou, A. C. (1920). The Economics of Welfare. London: MacMillan and Co. Ltd. ROCOL Working Group. (2000) Road Charging Options for London: A Technical Assessment. London: The Stationary Office. www.hmso.gov.uk/acts/acts2000/20000038.htm. Accessed on May 25, 2002.

Sansom, T., Nash, C., Mackie, P., Shires, J. and Watkiss, P. (2001) Surface Transport Costs and Charges: GB 1998. Final report to the Department of Environment, Transport and the Regions, Institute for Transport Studies, University of Leeds, Leeds, July. www.its.leeds.ac.uk/projects/STCC/downloads/SurfaceTransportCostsReport.pdf. Accessed on February 24, 2003.

Shepherd, S. P. and Sumalee, A. (2004). A Genetic Algorithm Based Approach to Optimal Toll Level and Location Problems. Networks and Spatial Economics, 4, 161179.

Transport for London (2001). Transport Statistics for London 2001. Transport for London. www.tfl.gov.uk/tfl/pdfdocs/stats2001.pdf. Accessed on July 2, 2003.

Transport for London (2002a). Congestion Charging: Public Transport Improvements Before. Transport for London, London. www.tfl.gov.uk/tfl/cc_improve_pt_before.shtml. Accessed on March 24, 2003.

Transport for London (2002b). London Travel Report 2002. Transport for London. www.tfl.gov.uk/tfl/reports library stats.shtml. Accessed on July 10, 2003.

Transport for London (2002c). Congestion Charging: The 11 key Numbers. Transport for London. 2002. www.tfl.gov.uk/tfl/cc fact sheet key numbers.shtml. Accessed on February 24, 2003.

Transport for London (2003a). Congestion Charging: Six Months On. Transport for London, London, October. www.tfl.gov.uk/tfl/downloads/pdf/congestioncharging/cc-6monthson.pdf. Accessed October 23, 2003.

Transport for London (2003b). Central London Congestion Charging Scheme: Three Months On. Transport for London, London, June. www.tfl.gov.uk/tfl/pdfdocs/congestion charging/cc-three-month-report.pdf. Accessed June 25, 2003.

Transport for London (2003c). Impacts Monitoring Programme: First Annual Report. Transport for London, London, June. www.tfl.gov.uk/tfl/cc_monitoring.shtml. Accessed on June 25, 2003. 
Transport for London (2004) Congestion Charging - Update on scheme impacts and operations (London: Transport for London).

www.transportforlondon.gov.uk/tfl/downloads/ pdf/congestion-charging/cc12monthson.pdf.

Verhoef, E. (2002). Second-best Congestion Pricing in General Networks: Heuristic Algorithms for Finding Second-Best Optimal Toll Levels and Toll Points", Transportation Research B, 36(8), 707-729.

Walters, A. (1961) The Theory and Measurement of Private and Social Cost of Highway Congestion. Econometrica, 29(4), 676-699.

Westminster City Council (2003). Congestion Charging - Business survey: Results of Congestion Charging Survey.

www.westminster.gov.uk/roadsandstreets/congestioncharging/business_form.cfm

Zhang, X. and Yang, H. (2004), The Optimal Cordon-based Network Congestion Pricing Problem. Transportation Research B, 38, 517-537. 